\title{
Language is a symbol of our national pride
}

\author{
Yulduz Shamuratova ${ }^{1}$ \\ ${ }^{1}$ Faculty of Turkish Languages., Nukus State Pedagogical Institute,Uzbekistan
}

\begin{abstract}
The mother tongue is as sacred as the Motherland, parents and family are precious to everyone. When a child is born, he is given a name in his mother tongue, Allah is said in his mother tongue, and he speaks words in his mother tongue. The notion of the mother tongue is therefore a sacred value instilled in the blood of each of us. He plays an important role in finding a small place in our society, in shaping us into mature people who will benefit the people. The mother tongue is an example of the unity and solidarity of the nation, its pride and spirit.
\end{abstract}

Keywords: Motherland, mother tongue, Language, organizations and enterprises.

\section{Introduction}

Language is the inexhaustible treasure of the nation, its priceless property. Because the history of the people, its cultural and spiritual heritage, traditions and customs are embodied in it. In the words of the first President Islam Abduganievich Karimov: Understanding the minority, national connection is formed through language. We must always keep these ideas in mind. Indeed, your language is invaluable in the development and progress of a nation[1].

\section{The results}

There are many important dates in history that deserve to end with golden letters. One such day is October 21, 1989. This day is significant in that Uzbek has been given the status of the state language. It is no exaggeration to say that this was the first step towards independence. Because at that time, independence had not yet been achieved. The adoption of the Law of the Republic of Uzbekistan on the State Language serves as an important legal basis for strengthening the value of our native language, which is a reflection of our great pride, spirituality, and further enhancing its global status.

The status of the state language is of great importance. In fact, the existence of this status can be called the basis of state independence, I think. After all, in the former Soviet Union, the Russian language dominated all legal and regulatory documents, newspapers and magazines, television, government agencies, organizations and enterprises, the judiciary in general, in all spheres of life. Whether understood or not, the education system was conducted in that language and it was strictly required. Like all our national values, our native language has been insulted. This issue has been implemented at the level of state policy. In particular, as the Russian historian Skobelev said: "It is not necessary to use weapons to destroy the nation, it is necessary to destroy its language, spirituality, literature, so that the nation will be less[2]."

\section{Main part}

Granting the Uzbek language the status of the state language will increase its status, expand its scope and have a great positive impact on its development. After the adoption of the law on the creation of the Uzbek alphabet based on Latin on September 2, 1993, a wide range of opportunities was created to take a worthy place in the world communication system, especially to connect to the Internet. As a result, the number of people interested in the Uzbek language and trying to organize it is growing worldwide. This has opened the way for the use of our language in the international arena. In fact, the Uzbek language is one of the richest in the world. According to scientists, our language is 80,000. It should also be noted that a language with many synonyms is the most convenient and richest language for organization. We all know that in the Uzbek language there are not one, but several synonyms that can be used instead of one word. It is a great happiness for every nation to be able to communicate freely in their little mother tongue. Because there are so many nations, peoples, and languages in the world. But, unfortunately, not all of them have the right to speak a language called by the name of the nation to which they belong[3].

There are many countries where the official language is the official language. It is also unfortunate, of course, that there are many higher languages that are not used at all today. Thankfully, our native language has the status of the state language, one of the world-recognized languages with a huge vocabulary. His position is reflected in all legal and normative documents, including our Constitution[4]. 
Article 4 of our Basic Law states: The state language of the Republic of Uzbekistan is Uzbek. We love our mother tongue and are proud of it. This pride carries a great responsibility at the same time. It is also to ensure the purity of the language. But, unfortunately, there are many cases of misuse of foreign expressions in the language of young people. I think the main reason for this attitude is that they want people to think that they know foreign languages. They try to present themselves as a streamlined, highly cultured people, and as a result, on the contrary, they look bad to everyone. It is true that foreign languages should be organized and treated with respect, but this does not mean that we should add foreign language phrases to our language. An example is the area where we live. The reason is that the fraternal peoples Kazakhs, Turkmens, Uzbeks, Karakalpakstan - have long lived in harmony here. They all have a high respect for each other's national traditions, customs and mother tongue. In particular, the establishment of the Faculty of Turkic Languages in our university and the fact that education is conducted in these languages is another proof of our opinion [5].

In the streets, markets and other public places, we see that all posters, from advertisements, are displayed in a foreign language (including Russian). Despite the fact that in the territory of the Republic of Karakalpakstan, where we live, there are not one, but two state languages (Uzbek and Karakalpak), the widespread use of Russian, I think, is not good [6].

Although there are few alternatives to the words in some advertisements in our language, they are still published in a foreign language. True, it may be intended to make it easier for tourists to come here. But think about it, why should we give up our little language for the sake of others? On the contrary, isn't it good that they try to understand and organize our language? In fact, I think it will increase the number of organizers of our native language and strengthen its international position. For example, in the Turkish state, other language expressions are never used in a small language, and even neologisms are chosen as an alternative to Turkish for all concepts [7].

After all, the purity of the mother tongue means national pride. In general, each of us should make a small contribution to the further development and growth of the Uzbek language [8]. It is the duty and sacred duty of each of us to love and respect the language!

\section{Conclusions}

It should be noted that the native language, its position, scope, as well as the problematic situations, achievements and shortcomings should be discussed not only in October each year, but also in practice. As a result of the growing popular culture today, the purity of our language is likely to be lost as a result of the corrupt Garbona way of life. It should not be allowed to be invaded by foreign elements. In addition to oral speaking, serious attention should also be paid to written literacy on a regular basis.

\section{References}

[1] Qushimov, B., Ganiev, I. M., Rustamova, I., Haitov, B., \& Islam, K. R. (2007). Land degradation by agricultural activities in Central Asia. Climate Change and Terrestrial Carbon Sequestration in Central Asia; Lal, R., Suleimenov, M., Stewart, BA, Hansen, DO, Doraiswamy, P., Eds, 137-146.

[2] Sanaev, G., Kim, K. R., Hasanov, S., \& Ganiev, I. (2015). Review of postharvest aspects of fruits and vegetables subsector in Uzbekistan. Connecting local and global food for sustainable solutions in public food procurement, 14, 557.

[3] Hamzaev, A. X., Astanakulov, T. E., Ganiev, I. M., Ibragimov, G. A., Oripov, M. A., \& Islam, K. R. (2007). Cover crops impacts on irrigated soil quality and potato production in Uzbekistan. Climate Change and Terrestrial Carbon Sequestration in Central Asia, 349.

[4] Ganiev, I., Sanaev, G., \& Pardaev, K. (2018). Career expectations of undergraduate and graduate students at agricultural universities in Uzbekistan (No. 179). Discussion Paper, Leibniz Institute of Agricultural Development in Transition Economies.

[5] Stirzaker, RJ (2003). When to turn the water off: scheduling micro-irrigation with a wetting front detector. Irrigation Science, 22 (3-4). Pp. 177-185.

[6] Hutchinson, PA, Stirzaker, RJ (2000) A new method and device for scheduling irrigation. Irrigation Association of Australia, May 23-25, 2000 National Conference. Pp. 584-592.

[7] Murodov Otabek Ulugbekovich, Kattayev Bobir Sobirovich, Saylixanova Maftuna Komiljonovna, \& Ibodov Islom Nizomiy o`g`li. (2020). Smart irrigation of agricultural crops. Middle European Scientific Bulletin,3, 1-3. https://doi.org/10.47494/mesb.2020.3.16

[8] Otamurodova, M. . (2020). Scientific researches on the journalism esp in foreign universities and in Uzbekistan journalism and mass communication university. Middle European Scientific Bulletin, 3, 7-9. https://doi.org/10.47494/mesb.2020.3.18 